\title{
アジア地域の経済成長とエネルギー消費構造に関する研究
}

\section{STUDY ON THE ENERGY DEMAND IN RESPONSE TO THE ECONOMIC DEVELOPMENT IN EAST ASIAN COUNTRIES}

井村秀文* - 白土廣信 Hidefumi IMURA*, Hironobu SHIRATSUCHI" and Ryo FUJIKURA**

\begin{abstract}
This study presents a comparative assessment on the relationship between economic growth, energy demand and the associated environmental impacts in three east Asian countries including Japan, South Korea and China. With rapid economic devclopment, there has been a significant growth of energy consumption and the associated carbon dioxide emissions in these countries, and this trend is expected to become more prominent towards the next century. In China, in particular, coal plays an important role as a major primary energy source, and energy intensity of production is notably high. As a result, air pollution control and the stabilization of carbon dioxide emission in China have become an important policy objective both on the national and international levels. In South Korea also, air and water pollution problems have become visible with its rapid development, and the current environmental conditions are very similar to those in Japan in the late 1960s. Overall, energy demand in South Korea and China exhibit many similarities to those which Japan experienced with its rapid economic growth .
\end{abstract}

KEYWORDS; energy and environment, economic development in Asia, $\mathrm{CO}_{2}$ emission, global warming

\section{1.はじめに}

日本の高度経済成長が始動したのが1955年頃とすると，それから約15年遅れの1970年頃に韓国経済の躍進 が，そして，1980年代には中国とASEAN諸国の急速な経済成長が始まった。経済成長に伴うエネルギー消費 量の増加は, $\mathrm{CO}_{2}, \mathrm{SO}_{2}$ 等の污染物質排出量の增大をもたらす。日本では, 高度経済成長開始後10年にして大 気污染や水質污濁等の激甚な公害問題と自然破壊に直面することになったが，その後の対策によって状況は大 きな改善をみた。これに対して，韓国や中国では目下公害問題が深刻化している最中である。

日本の例に見るように，地域的な公害問題に対しては，各種の污染物質除去技術（"end-of-pipe technology"） によってかなりの程度まで問題解決が可能である。しかし，化不燃料の大量消費によって引き起こされる地球 温暖化には，当面のところ抜本的な防止策がなく，顕在化する環境問題の中でもとりわけ大きな問題となって いる。世界の $\mathrm{CO}_{2}$ 排出量に対するアジア諸国の寄与率は現在すでに $20 \%$ に達しているが，これら諸国の経済成 長が現在のペースで持続するとすれば，その比重がさらに増すことは必至である。日本も含めて，21世紀の世 界の経済成長中心と目されるアジア地域でのエネルギー消費抑制が，地球温暖化対策の上で重要な課題になっ ている。

・ 九州大学工学部環境システム工学研究センター

Institute of Environmental Systems, Faculty of Engineering, Kyushu University

“環境庁地球環境部

Global Environment Department, Japan Environmental Agency 


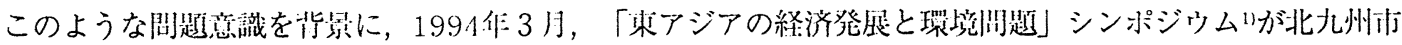

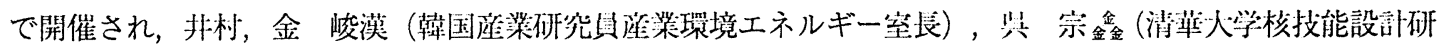

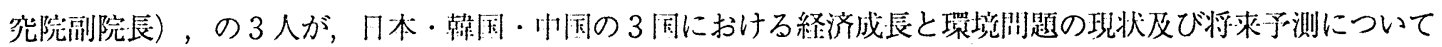
報告を行った。本論においては，これら 3 つの報告及び既報2) ・各種統計資料3・文献4を基に，上記 3 国の工 ネルギー消費構造と環境問題, 特に $\mathrm{CO}_{2}$ 排出量についての知見を整理し, 各国において今後予想される経済成 長と環境負荷発生の関係，求められる対策等について考察する。

\section{2.日・韓・中 3 国の経済成長とエネルギー消費の現状}

経済成長とエネルギー需要には強い相関がある。 特に, 重化学工業中心の工業開発, 民生機器の普 及，モータリゼーションの進展というサイクルの中 で，経済成長とともに国民1人当たりエネルギー消 費量は増加の一途にある。日・韓・中について，こ れを比較したのが図 1 である。

国民一人あたり一次エネルギー消費量で見れば, 1991年の中国の水準は, 韓国の1970年代初頭の水 準，日本の1950年頃の水準にあるが，その差は急速 に縮小されるに違いない。ここで，中国の巨大な人

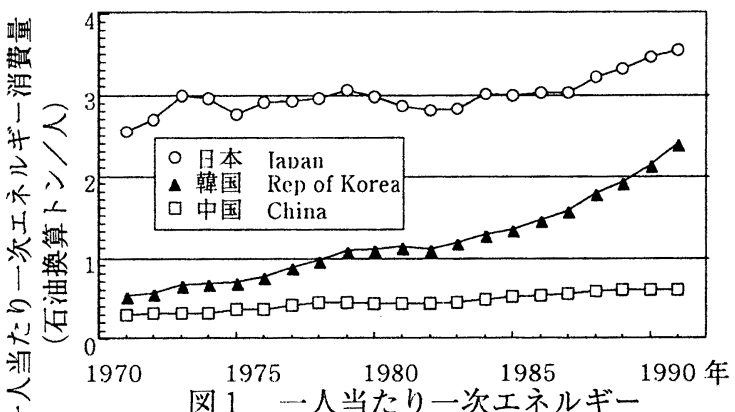

図 1 一人当たり一次エネルギー 消費量の変化

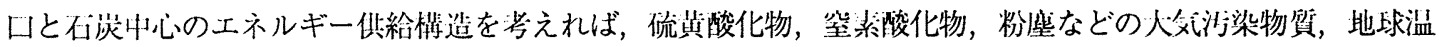
暖化をもたらす $\mathrm{CO}_{2}$ の発生量は膨大なものになる。

また，部門別最終エネルギー消費の棈成割合をみたのがそれぞれ図2である。これをみると，日本では産業

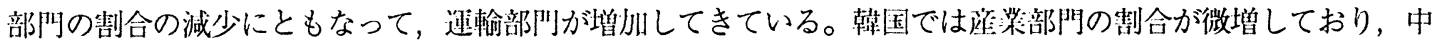
国では1971年から1991年までほとんど構成割合に変化がなく，産業部門の占める割合が非常に大きい。

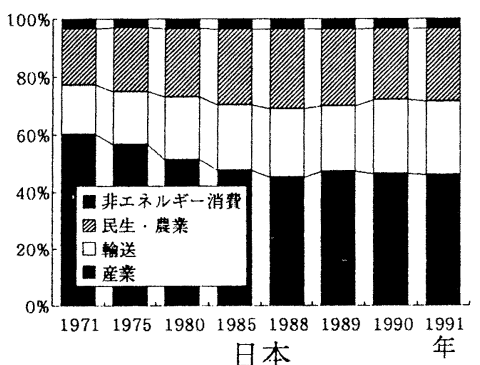

日本

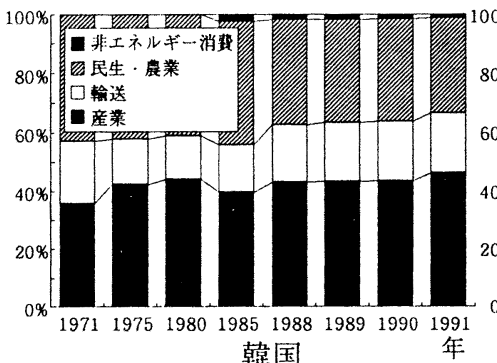

韓国

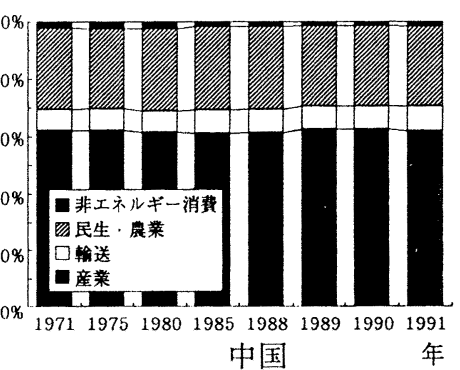

中国

脳 2 部川斺最終エネルギー消少

\section{3 .日・韓・中 3 国のCO $\mathrm{CJ}_{2}$ 出構造の比較}

\section{1 分析方法}

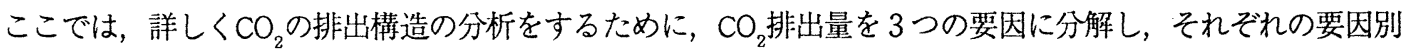
寄与度を比較する。

単位GDP当たりの $\mathrm{CO}_{2}$ 排出強度 $\varepsilon$ を要因分解すると次式のようになる：

$$
\varepsilon=\mathrm{CO}_{2} / \mathrm{GDP}=\left(\mathrm{CO}_{2} / \mathrm{Eff}\right) \cdot(\mathrm{Eff} / \mathrm{Epr}) \cdot(\mathrm{Epr} / \mathrm{GDP})=\xi \cdot \eta \cdot \zeta
$$

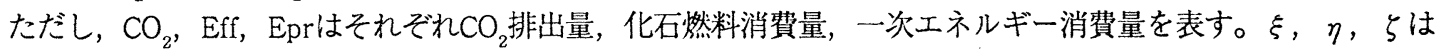
それぞれ，化石燃料のCO2強度，化石然料依存度，単位生産当たりのエネルギー消費量である。

\section{2 分析結果}

図 3 に計算結果を示す。 $\xi\left(\right.$ 化石燃料の $\mathrm{CO}_{2}$ 強度）をみると, 中国は一貫して石炭への依存度が高く, 日本, 韓国は石炭から石油，天然ガス等へとシフトしていることが読み取れる。また，（化石然料依存度）につい 


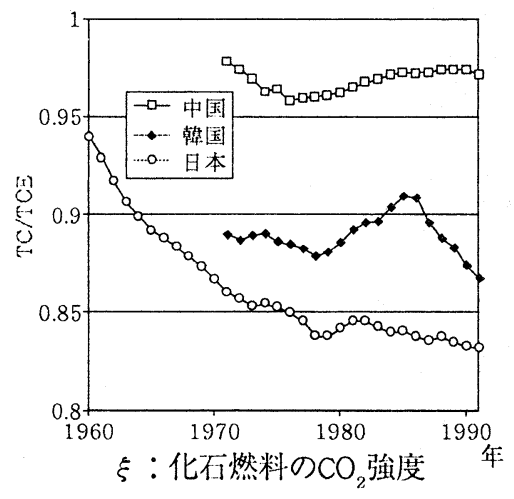

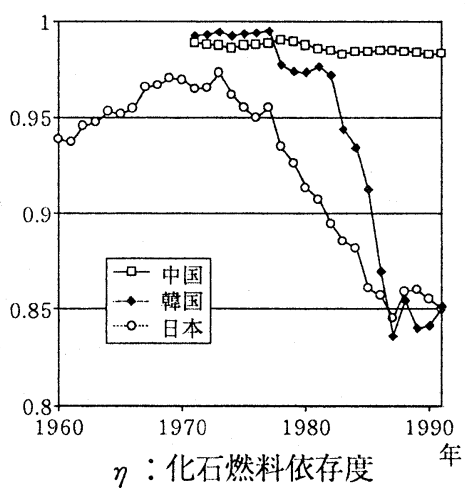

図 $3 \mathrm{CO}_{2}$ 排出構造分析結果

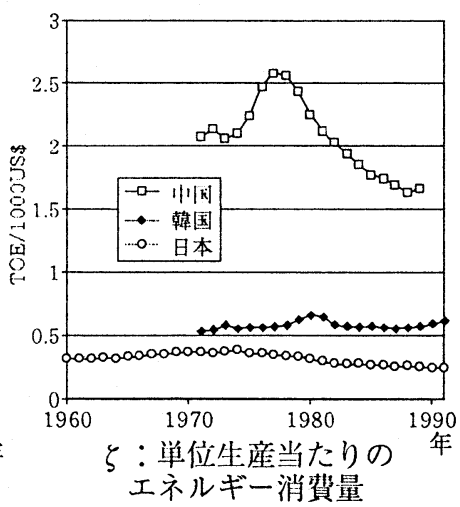

エネルギー消賀量

ては日本，韓国の化石然料依存度が減少していることがわかり，新エネルギー（原子力など）の開発が進んで いることが示されている。一方，と（単位生産当たりのエネルギー消临量）については，中国の減少が目立っ ているが，日本・韓国と比較するとまだ約 3 倍の值である。

\section{4.日・韓・中 3 国のエネルギー消費構造の要因分析}

\section{1 要因分析モデル}

最終エネルギー消費部門別構成比の推移をみると日本，韓国，中国に共通の傾向として，産業部門の占める 割合が高い（図 2 ）。そこで要因分析モデルを用いて産業部門のエネルギー消費構造を分析する。

エネルギー需要をEとすると，Eは次式で表される：

$\mathrm{E}=\Sigma(\mathrm{Ei} / Z \mathrm{i}) \cdot(Z \mathrm{i} / Z) \cdot Z$

これから，ある期間におけるEの変化分 $\Delta \mathrm{E}$ は，次のように槑因分解できる。

$\Delta \mathrm{E}=\Sigma \Delta(\mathrm{Ei} / \mathrm{Zi}) \cdot(\mathrm{Zi} / \mathrm{Z}) \cdot \mathrm{Z}+\Sigma(\mathrm{Ei} / \mathrm{Zi}) \cdot \Delta(\mathrm{Zi} / \mathrm{Z}) \cdot Z+\Sigma(\mathrm{Ei} / \mathrm{Zi}) \cdot(\mathrm{Zi} / \mathrm{Z}) \cdot \Delta Z+$ 交絡項

$=($ 原単位の変化による変化分 $)+($ 構成割合の変化による変化分 $)+($ 生産量の変化による变化分 $)$ 十交絡項

ここに, $\mathrm{E}$ : エネルギー消費量, $Z$ : 生産量, $\mathrm{i}$ : 品類

なお，日本，韓国は製造業（9 分類），中国は物質生産部門（5 分類）について分析を行った。

4. 2 分析結果

眓 4 をみると，日本ではオイルショックを機にエネルギー消費原単位の大幅な改善が行なわれ，エネルギー 多消費産業からエネルギー小消費産業へと構成割合が変化している。また, 生産量の变化による要因も隇少傾

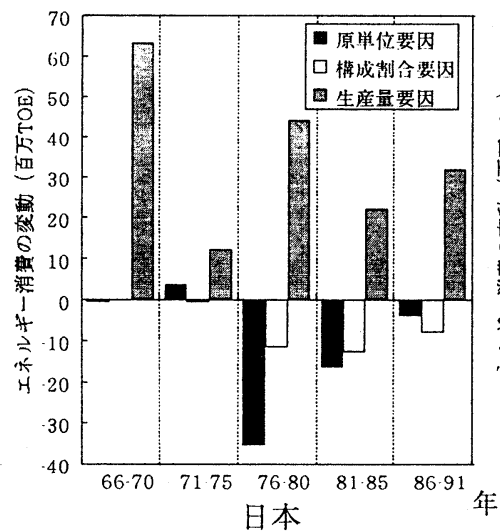

日本

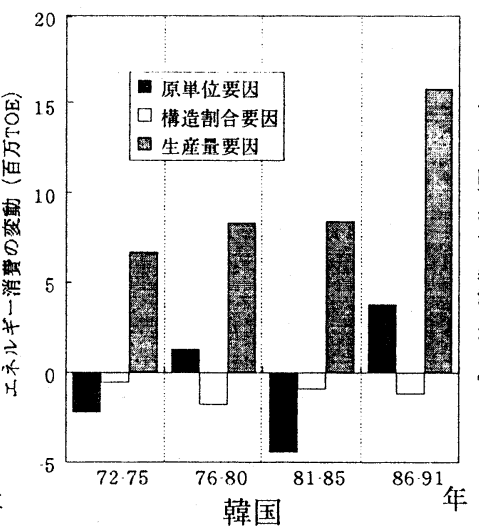

図 4 要因分析結果

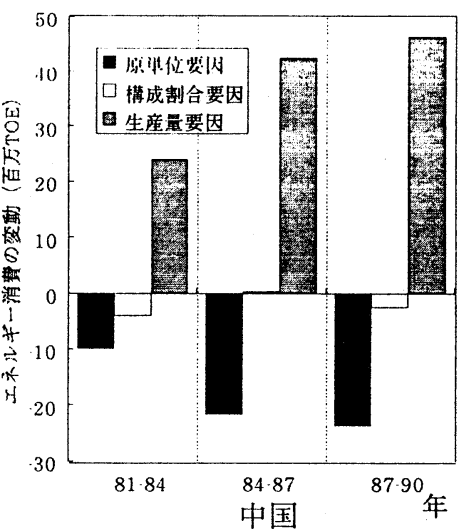

中国 
向にある。韓国についても，エネルギー多消費産業からエネルギー小消費産業へと構成割合が変化している が，それ以上に生産量の変化による要因が增加している。中国については，年々原単位の低下が見られるもの のそれ以上に生産量の変化による要因が增玑している。また，靚成割合の変化はあまり見られない。

\section{5. 中国における将来のエネルギー需要予測と一次エネルギー構成の分析}

5. 1 シナリオ

アジア諸国のゆにあって，その巨大な人口と成長ポテンシャルから考えて，中国の今後のエネルギー消貿動 向が地球温喛化刘策に大きな意味を持つことは礁坚である。兴の研究グループは, INETと称するエネルギーシ ステム分析モデルを棈築し，2050年までの長期にわたり，中国の社会経済発展について幾つかのシナリオを 設定した上で，エネルギー需給と $\mathrm{CO}_{2}$ 排出量の将来予測を行っている。以下は，その概要紹介である。

将来のエネルギー需要に影響を与える要素としては，主に経済発展，人口増加，国民経済の産業構造，技術 の進歩及びエネルギー価格などの需要管理政策などがある。その将来についての基本シナリオは以下の通りで ある。

（1）人口：一人っ子政策と人口増加の抑制は中国政府の長期に渡る基本的政策である。今世紀末までに，人 口の自然增加率を $1.25 \%$ 以内に抑え，女性の総和出产率を1990年の 2.3 から先進国の現在の平均レベルである 2.0以下に抑制し，21世紀半ばには人口を15億人前後で維持したいとしている。

（2）経済成長：中国政府は21世紀半ばには一人当たりのGNPを一般先進国レベル程度（現在のスペイン，ギ

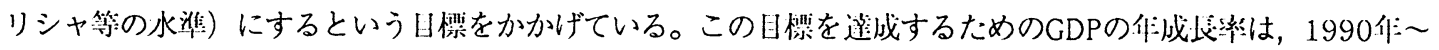
2000 年は $8 \% ， 2000$ 年〜 2020 年は $5 \%$ であり，2020年～2050年の 60 年間の平均年間成長率は $4.5 \%$ ある。

(3) 産業構造：一人当たりのGDPが成長するにつれて，それぞれの産 業のGDP構成における割合に変化が生じる。世界のほとんどの先進国が その発展過程で経験した变化から考えて，2050年には，農業の割合が 1990年の $28.4 \%$ から $10 \%$ 以下に下がり，工業が44.4\%から40\%前後に 下がる。また，サービス業は $27.2 \%$ から50\%以上に上昇する。ただし， 交通輸送は，5\%から6〜7\%に上昇と変化は小さい。

（4）エネルギー技術：将来のエネルギー開発，転換，利用技術及び需 要管理政策に二つのシナリオを仮定する。一つはBAU（buisiness as usual）シナリオで，もうひとつは対策（Policy）シナリオである。BAU シナリオでは，エネルギー供給は 国内エネルギー資源の開発と利用 を基本とし，過去 10 年間にわたっ て行ってきた省エネ政策を続ける ことによって，エネルギー消紧弾 性係数は下降を続ける。刘策シナ リオはBAUシナリオを基礎にした 上で, より一層の省エネとエネル ギー代替を強化し， $\mathrm{CO}_{2}$ 排出替制に 拍車をかけるものである。

人口シナリオを図 5 に，経済成 長（低成長ケース，高成長ケー ス）に関するシナリオを表 $1 ， 2$ に 示す。

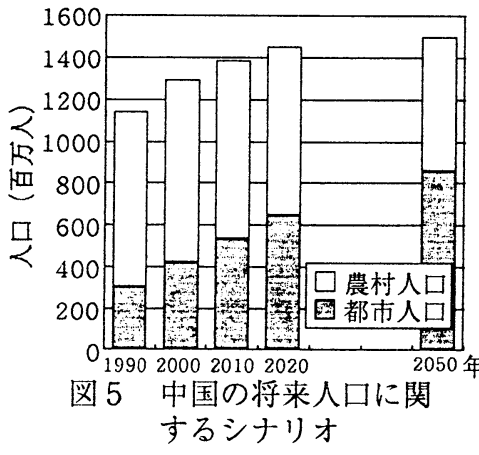

表1 経済成長とエネルギー需要（低成長ケース，中国）

\begin{tabular}{|c|c|c|c|c|c|}
\hline & & 1990 & 2000 & 2020 & 2050 \\
\hline \multirow{10}{*}{$\mathrm{BA} \mathrm{U}$} & G D P (10管元) & 1.769 & 3,818 & 10,131 & 24,590 \\
\hline & 一次エネルギー総需要 $(\mathrm{M} \mathrm{t} \mathrm{c} \mathrm{e})$ & 987 & $1,490.6$ & 2.434 .6 & 3.681 .9 \\
\hline & 電力需装 $(\mathrm{T} w h)$ & 623.0 & 1.161 .9 & $2,645.6$ & $4,814.2$ \\
\hline & 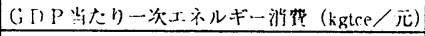 & 0.56 & 0.39 & 0.24 & 0.15 \\
\hline & G D P 成长䓨 (\%) & \multicolumn{2}{|l|}{8.0} & \multicolumn{2}{|c|}{3.0} \\
\hline & エネルギー清費增加率（％） & 4.20 & 2.48 & \multicolumn{2}{|c|}{1.39} \\
\hline & 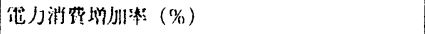 & 6.43 & 4.20 & \multicolumn{2}{|c|}{2.02} \\
\hline & 対 G D Pエネルギー消賽弾性值 & 0.53 & 0.50 & \multicolumn{2}{|c|}{0.46} \\
\hline & 対 G D P電力消費弾性値 & 0.80 & 0.84 & \multicolumn{2}{|c|}{0.67} \\
\hline & 年間省エネルギー率 (\%) & 3.55 & 2.40 & \multicolumn{2}{|c|}{1.55} \\
\hline \multirow{10}{*}{ 刘策 } & G D P (10億元) & 1.769 & 3,818 & 10.131 & 24,590 \\
\hline & 一次エネルギ一紛需要 $(\mathrm{M} \mathrm{t} \mathrm{c} \mathrm{e} \mathrm{)}$ & 987 & $1,464.0$ & $2,218.3$ & $3,157.4$ \\
\hline & 電力需要 $(T w h)$ & 623.0 & 1.148 .6 & $2,531.8$ & $4,508.2$ \\
\hline & G D P 当たり一次エネルギー消蓝（kgtce／元) & 0.56 & 0.38 & 0.22 & 0.13 \\
\hline & G D P 成辰案 (\%) & 8.0 & 5.0 & \multicolumn{2}{|c|}{3.0} \\
\hline & エネルギー消賴增加率（\%) & 4.02 & 2.10 & \multicolumn{2}{|c|}{1.18} \\
\hline & 電力消費增加率（\%） & 6.31 & 4.03 & \multicolumn{2}{|c|}{1.94} \\
\hline & 対 GD Pエネルギー消萺弾性值 & 0.50 & 0.42 & \multicolumn{2}{|c|}{0.39} \\
\hline & 对 G D P電力消賫弾性值 & \multirow{2}{*}{$\begin{array}{l}0.19 \\
3.80\end{array}$} & \multirow{2}{*}{$\begin{array}{l}0.80 \\
2.70\end{array}$} & \multicolumn{2}{|c|}{0.65} \\
\hline & 年䦥省エネルギ一事（\%) & & & \multicolumn{2}{|c|}{1.74} \\
\hline
\end{tabular}




\section{2 予測結果}

上述の基本構想にそって, 1990 年から2050年までのエネルギー需 要構造が試算分析されている。こ の結果によると，2050年における 中国の一次エネルギー総需要量は 低成長ケースのBAUシナリオ，対 策シナリオでそれぞれ 3682Mtce，3157Mtceとなる（表 1, 2)。

図 6 は最終エネルギー消費の変 化を示したものであるが，経済成 長に伴ってエネルギー消費量は增 加している。構成割合でみると, 産業部門と農業部門は減少してお り，逆にサービス部䅀と迺輸部鬥 が増加していることが読みとれる。

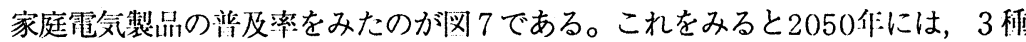
類の家電品すべての普及率について都市部と宸村部の格差が著しくなっている。圆家庭 1993年現在，日本では電気冷蔵庫，電気洗濯機，エアコンの普及率はそれぞれ 98.0\%，98.4\%，72.3\%であるが，中国では，2050年に電気洗潍機 (都心部) が ようやく現在の日本のレベルに追いつくことになる。

また，エネルギー源別構成比の変化をみたのが図 8 であるが，その他（原子力など）の占める割合が増加 しており，石炭消費の割合が隇少していることがわか る。

次に, 図 9 は $\mathrm{CO}_{2}$ 排出の削隇効果をみたものである。 BAUシナリオの場合と比べると，対策シナリオの方が ある程度大きな $\mathrm{CO}_{2}$ 排出削滅効果をあげている。こうし たシナリオにそって中国のエネルギー消費が，順調に 石炭中心からクリーンエネルギーへとシフトされれば 確実に環境負荷の低減が達成ができることが示されて いる。しかし，見方によれば， $\mathrm{CO}_{2}$ 排出増加のトレンド
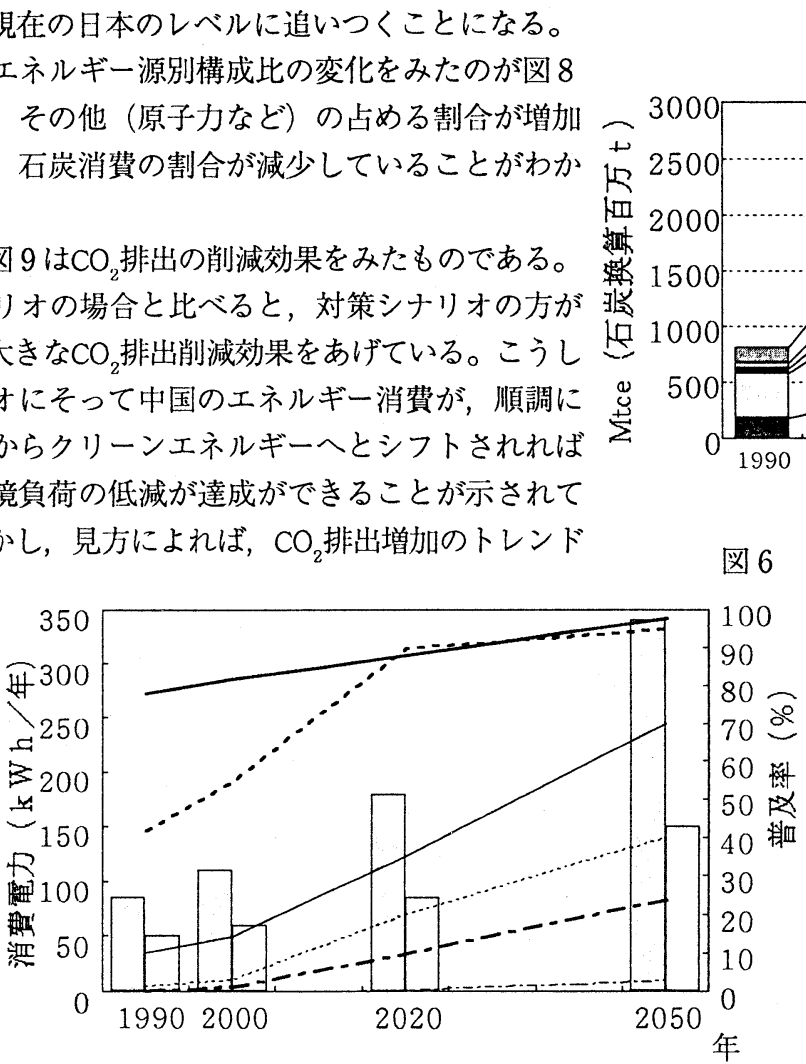


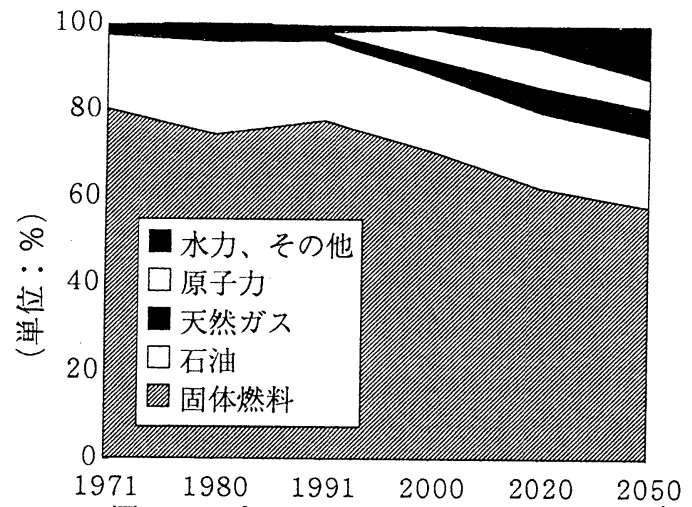

図 8 エネルギー源別構成比の变化 年 (低成長ケース，中国）

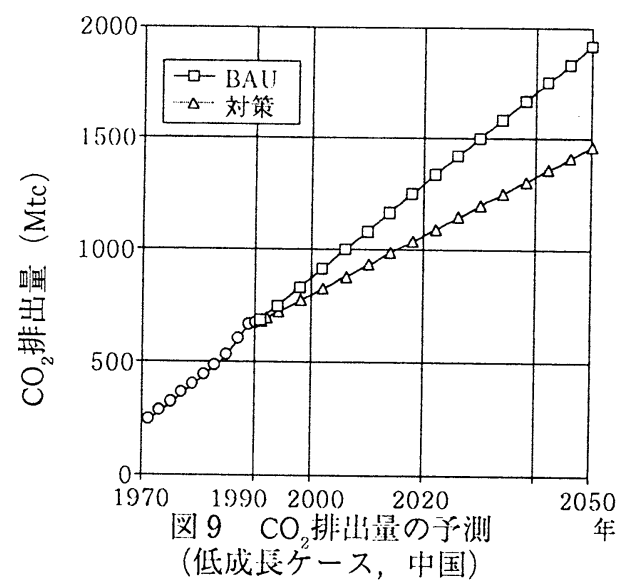

そのものに大きな変化はなく，問題の発現が们一仨か先延ばしされるだけとも言える。

\section{6. 韓国の産業別 $\mathrm{CO}_{2}$ 排出量の推移とその変化の要因分析}

6. 1 韓国の産業構造とCO 2 排出の特性

韓国の経済成長パターンは，15〜20年程度の遅れをもってあたかも日本の後を追従してきており，近年そ の時問差は縮小されつつあるようである。この意味で，日韓両国には共通点が多い。しかし，両国の間には， 産業構造の面でまだ大きな差がある。石油危機を経て，日本産業が脱重化学工業化，サービス化への傾斜を強

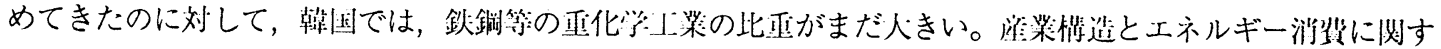
る日本と韓国のこうした暹いを分析することは，NIESとしての韓国の特徵を浮き彫りにするとともに，経济成 長と環境負荷発生との関係についての 1 つの普遍的発展法則を示唆するものである。

以下では,このような視点から，韓国産業のエネルギー消費特性に関する金1)の分析結果を紹介し，韓国産 業の特性を考察する。

金の報告によれば，最近では産業部門でのエネルギー消費増加が総消費量の増加を押し上げており，そのた めに産業部門における $\mathrm{CO}_{2}$ 排出抑制対策が早急に必要だとされている。そこで彼は $\mathrm{CO}_{2}$ 排出を抑えるための効 果的な政策を立てるために，各産業部門で $\mathrm{CO}_{2}$ 排出量がいかなる要因によって変化してきたのかをまず分析し なければならないと述へ，韓国における過去10年間における $\mathrm{CO}_{2}$ 排出量の変化とその要因を分析している。な お，分析には65部門の産業連関表を使用しており，対象年度は1983年，1986年，1989年および1992年であ る。

\section{6. $2 \mathrm{CO}_{2}$ 誘発係数}

間接的排出を考虑した金額ベース（90年価格）での弾位生産当たり $\mathrm{CO}_{2}$ 排计量（単位：TC／百万ウォン）を $\mathrm{CO}_{2}$ 誘発係数とすると, 表 3 は製造業でのCO $\mathrm{Cl}_{2}$ 拙係数を示し たものである。やはり鉄鋼, 非金属鉣物製品などの数字が大き くなっている(表 3)。

\section{6. $3 \mathrm{CO}_{2}$ 排出量の要因分析}

1992年における65部門全体の $\mathrm{CO}_{2}$ 排出量は，1983年より 2269万トンの增加をみた。その要因は 1 . 生産規模の拡大,

2. 排出係数の変化に大別される。

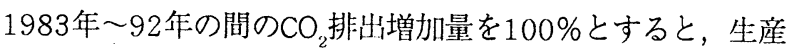
額増加による寄与度は $107 \%$ となっている。これは, $\mathrm{CO}_{2}$ 排出 係数に変化がなかったとすれば，同期間に $\mathrm{CO}_{2}$ 排出量は実增加

表 3 製造業 (韓国) $9 \mathrm{CO}_{2}$ 排出係数 (单位：TC/百万ウォン)

\begin{tabular}{|c|c|c|c|}
\hline 部門 & 誘発係数 & 部門 & 誘発係数 \\
\hline 鉄鋸 & 0.9429 & 木材・木製品 & 0.1756 \\
\hline 非金属鉣物製品 & 0.8315 & 印刷・出版 & 0.1723 \\
\hline 金属製品 & 0.3574 & ブラスチック & 0.1561 \\
\hline 製紙 & 0.3017 & 飲食料・多バコ & 0.1512 \\
\hline 化学製品 & 0.3005 & その他製造業 & 0.1412 \\
\hline 石油·石炭製品 & 0.2506 & 精密機械 & 0.1315 \\
\hline 栱維 & 0.2236 & 衣服 & 0.1245 \\
\hline 一般機械 & 0.2072 & 電気.電子 & 0.1242 \\
\hline 非鉄金屈 & 0.1997 & 製革·革製品 & 0.1183 \\
\hline 輸送機械 & 0.1808 & ゴム & 0.1004 \\
\hline
\end{tabular}

(年度：1992年) 
量2268万トンより7\%多い2423万トンに達するということを意味する。し かし同期間の65部門全体のCO 排出係数が0.1262から0.1190へと低下して

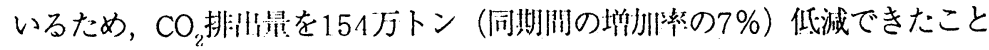
になる（表４）。

同様にして製造業分野を対象に1983〜92年のCO ${ }_{2}$ 排出增加要因を業種別 に詳しくみたものが表 5である。これをみると，ゴム $(-317 \%)$ ，電気・

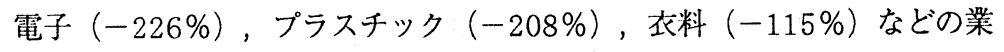
種ではCO ${ }_{2}$ 排出係数の変化が排出量の大幅削減に寄与している。しかし, 石 油・石炭製品 (149\%)，製革・革製品（55\%）などの業種においては，逆 に $\mathrm{CO}_{2}$ 排出量を増加させる要因として作用している。一方で生産額の変化は 軽工業, 重化学工業のどちらにおいても $\mathrm{CO}_{2}$ 排出量を增やす要因となった が，石油・石炭製品業種だけは同期間中に生産規模がむしろ縮小したため, 唯一マイナスの数值がでている。

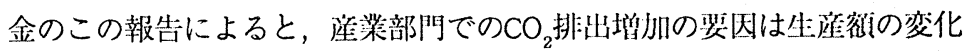
が決定的であり，排出係数の変化については業種によって抑制につながる場 合とその逆があると結論されている。

\section{7.おわりに}

本報告では，アジア地域（日本，韓国，中国）について，エネルギー消費 と $\mathrm{CO}_{2}$ 排出について考察した。

現在，アジアの経済発展に世界の関心が集まっている。今後21世紀の世界 経済を見通すには多くの不確定要素があるが，アジアが世界経済の成長中心 の一つであり続けると予想する識者は多い。したがって，アジア地域の現状 を把握し，将来の動向を検討することは地球環境的に重要な意味を持つ。

東アジアの経済成長と工業化は，エネルギー消費の増大とそれにともなう 污染物質排出量の増大に直面する。もち万ん，日本のような先進国において は，産業構造のシフト，ライフスタイル等の消費構造の変革, 人口増加の低 下によって, 量的成長から質的成長への転換を実現し, 環境負荷の増大カー ブをかなり下方修正することは可能であろう。また，韓国も早晚日本の軌跡 を追随するであろう。しかし，中国及びASEAN諸国においては，社会的イン フラ (道路, 鉄道, 港湾, 住宅, 上下水道, 電力等) の整備のためにも, 個 人の消費欲求の充足のためにも，なおかなりの期間にわたって生産の量的拡 大が必要とされる。いずれにしても，程度の差こそあれこれらの国々では経济発展に伴う環境賁荷の增大は不 可避であり，それをどこまで抑制できるかが今後の重姴な問題である。

本研究は，（財）国際東アジア研究センターとの協力及び (財) 松下国際財団の援助により行ったものであ り,ここに感謝の意を表します。

\section{参考文献}

1) (財) 国際東アジア研究センター, 九州大学環境システム工学研究センター, 北九州市主催 : ICSEAD連続国際シンボジ ウム「成長の東アジア展望21」第一部「東アジアの経済発展と環境問題」

2)井村秀文他：東アジア地域の経済発展と環境問題 : 日本・韓国・中国の比較論的考察, 第 2 回地球環境シンポジウム講演 集, pp.268-274

3)日本エネルギー経済研究所：エネルギー・経済統計要覧, 省エネルギーセンター, 1994

4)Asian Development Bank : National Response Strategy for Global Climate Change : People’s Republic of China,

ADB T.A. No.PRC-1690, Second Progress Report, 1993. 